\title{
Predators, Predator Removal, and Sage-Grouse: A Review
}

Michael R. Conover, Jack Berryman Institute, Wildland Resources Department, Utah State University, Logan, UT

Anthony J. Roberts, Wildland Resources Department, Utah State University, Logan, UT

\begin{abstract}
Populations of sage-grouse (Centrocercus urophasianus; i.e., sage-grouse) have been in a decline since the nineteenth century. We used our research, unpublished reports, and scientific literature to identify which predators kill greater sage-grouse and to assess whether lethal control of these predators benefited the species. We also asked state wildlife biologists and scientists if they had ever witnessed a predator kill sage-grouse. We identified 266 instances where the predator responsible for depredating nests or killing juvenile or adult sage-grouse could be ascertained. Most adult sage-grouse were killed by eagles (Accipitridae), owls (Strigiformes), or coyotes (Canis latrans), except where red foxes (Vuples vulpes) were abundant. Based on nestcameras, most depredated eggs are taken by common ravens (Corvus corax), badgers (Taxidae taxus), or coyotes. There are too few studies to conclude that predator removal increases survival rates of juvenile or adult sage-grouse. No study has been conducted to determine if badger removal increases nest success of sage-grouse, and the only study on coyote removal produced ambiguous results. Several studies reported that more sage-grouse nests are successful (i.e., $\geq 1$ eggs hatched) in areas where common ravens were removed or in areas where raven densities were lower than in other areas. Populations of sage-grouse have been in a decline for over a century, and predators are unlikely to have played a role in the decline during most of this period, but increasing numbers of ravens since the 1970s may have contributed to the declining sage-grouse populations in recent decades.
\end{abstract}

Proceedings of the $18^{\text {th }}$ Wildlife Damage Management Conference. (J.B. Armstrong, G.R. Gallagher, Eds.). 2019. Pp. 4 